\title{
局所トンネル障壁高さの理論解析
}

\author{
戸塚 英臣・渡邊 聡* \\ 日本大学理工学部物理学科 嶫 101-8308 東京都千代田区神田駿河台 1-8-14 \\ *東京大学大学院工学系研究科マテリアル工学専攻 凿 113-8656 東京都文京区本郷 7-3-1
}

(2007 年 4 月 21 日受理)

\section{Theoretical Analyses of Local Tunneling Barrier Height Based on Ab Initio Calculation}

\author{
Hideomi Totsuka and Satoshi Watanabe* \\ Department of Physics, College of Science and Technology, Nihon University \\ 1-8-14 Kanda-Surugadai, Chiyoda-ku, Tokyo 101-8308 \\ *Department of Materials Engineering, The University of Tokyo, 7-3-1 Hongo, Bunkyo-ku, Tokyo 113-8656
}

(Received April 21, 2007)

\begin{abstract}
Theoretical studies on the local tunneling barrier height on an $\mathrm{Al}(100)$ surface are presented. First, the effect of localized states on the local tunneling barrier height $(\mathrm{LBH})$ is discussed. The bias polarity dependence of $\mathrm{LBH}$ on the $\mathrm{Al}$ (100) surface, containing a vacancy cluster in the layer next to the surface, is studied. It is found that the bias polarity dependence of the LBH can be attributed to the reduction in the effective potential and the change in the surface electron states by the applied bias voltage. Second, the effect of tip atomic species on the LBH is discussed. It is found that, for the tip-sample distance dependence of the LBH, the difference between measurements with the two atomic species is larger in the LBH than in the maximum barrier height evaluated from the calculated potential profile. Furthermore, it is found that the bias polarity dependence of the LBH measured with the Na tip shows behavior opposite to that measured with the Al tip. Finally, the difference in LBH by the approach and modulation methods is discussed. It is found that the change in modulation amplitude, which is caused by the force acting on the tip atom due to the applied bias voltage, can account for the observation that the modulation method provides smaller LBH values than approach method.
\end{abstract}

KEYWORDS : local tunneling barrier height, ab initio calculation, Al surface, scanning tunneling microscopy, work function

\section{1.は じめ に}

仕事関数は表面のさまざまな物性や化学的性質を左右 する量であるだけでなく, 表面から真空への電子放出を 決定する量でもある。このため古くから測定され研究さ れてきたが，近年ではその局所的な変化も測定されるよ うになってきた。特に最近, 走査型トンネル顕微鏡 (Scanning Tunneling Microscope, 以下 STM) を用いて原 子レベルの仕事関数といえる局所トンネル障壁高さ （Local Tunneling Barrier Height，以下 LBH）を測定する 試みが多数報告されている。 $\mathrm{LBH}$ 測定は，金属表面 ${ }^{1 \sim 3)}$
や半導体表面 ${ }^{4,5)}$, また自己組織化単分子膜に被覆され た金属表面 ${ }^{6}$ で行われている。さらに LBH は, 場所に よる值の変化を単に調べるだけでなく, Si 表面上の欠 陥の種類の同定 ${ }^{7,8)}$ や Si 表面に吸着したナノスケールの 有機分子のキャパシタンスの評価 ${ }^{9}$ などにも応用されて いる。したがって, LBH は表面の電子状態を反映した 基本的な物理量であるだけではなく, 応用上も有用な量 であると言える。しかし，後で述べるようにLBH の振 る舞いの物理的意味は十分に理解されているとはいえな い。本稿では，この点を念頭に筆者らがここ数年間に行 った理論研究 ${ }^{10 \sim 13)}$ を紹介する。 


\section{LBH 測定について}

理論研究の紹介に入る前に, LBH 測定の原理, 主な 報告事例, そして問題点を簡単にまとめておく。LBH 測定は, STMによって測定されたトンネル電流の探針 試料間距離依存性から次式を用いて評価される。

$$
\phi_{\mathrm{LBH}}=0.952\left(\frac{d \operatorname{In} I_{\mathrm{t}}}{d z}\right)^{2}
$$

ここで $I_{\mathrm{t}}[\mathrm{A}]$ と $z[\AA]$ は STM で測定されたトンネル電 流と探針試料間距離である。具体的には, Modulation 法 と Approach 法の二つの測定方法がある。Modulation 法 は, 探針を微小振動させた際のトンネル電流の変化を測 定し, それと（1）式を差分化した式から LBH を評価 する測定法である。一方 Approach 法は, 探針を試料表 面から離しながら測定した $\log I_{\mathrm{t}}-\mathrm{z}$ 曲線を関数でフィ ッティングし, その関数と（1）式から LBH を評価す る測定法である。Modulation 法には LBH 像と STM 像を 同時に測定できるなどの利点があるが，探針の振動の不 安定性や変調振幅のゆらぎのために得られた LBH 值は しばしば大きくばらつく。一方 Approach 法は, Modulation 法より LBH 值の再現性が高いが, $\log I_{\mathrm{t}}-\mathrm{z}$ 曲線が 直線からずれる探針試料間距離の領域では LBH に関す る情報を得ることが難しい ${ }^{14,15)}$ 。

（1）式の導出には，1 次元の矩形ポテンシャルで低 バイアス電圧の仮定のもと WKB 法により導出されたト ンネル電流の近似式

$$
I \propto \exp (2 \kappa z), \quad \kappa=(2 m \phi)^{1 / 2} / \hbar
$$

が用いられている。ここで $m$ は電子の質量, $\hbar$ はプラ ンク定数, $\phi$ は探針と試料表面の仕事関数の平均であ る。（2）式から直ちに（1）式が得られ，またこの近 似のもとで (1) 式で評価される LBH が局所的な仕事 関数に対応することがわかる。これまでに LBH 測定は 多数報告されている。例えば, 清浄 $\mathrm{Cu}(111)$ 表面と $\mathrm{Au} /$ $\mathrm{Cu}(111)$ 表面上の $\mathrm{Au}$ テラス位置で測定された LBH が他 の測定方法で得られた仕事関数の值とよい一致を示すこ と ${ }^{2,3)}$ ，また, $\mathrm{Au}$ 探針/ $\mathrm{Au}(111)$ 表面上で探針試料間距離 を一定にして测定された LBH がバイアス電圧の増加と ともに減少することが報告されている ${ }^{16)}$ 。一方, LBH 測定は応用面でも注目されている。例えば, グラファイ トの表面にある空孔欠陥と層間にある格子久陥は, STM 像では同じコントラストを示すが, LBH 像では逆 のコントラストを示す。したがって，LBH 测定により 欠骝の同定が可能となる ${ }^{17)}$ 。さらに, Si (100) 表面上に 吸着したシクロペンテン薄膜のキャパシタンスがバイア ス極性による $\mathrm{LBH}$ の差から評価され, その值は $1.3 \times 10^{-20} \mathrm{~F}$ であると報告されている ${ }^{9)}$ 。
しかし, LBH の測定值やその振る舞いの持つ物理的 意味は未だ十分に理解されてはいない。例えば，（1） 式の導出時には試料表面や探針の原子構造や高バイアス 電圧の影響などは考慮されていないため, それらが LBH にどのように影響するかは十分に理解されている とは言えない。また, $\mathrm{Au}$ 探針で測定された $\mathrm{Au}(111)$ 表 面上の LBH の值が非常に小さいこと ${ }^{18,19)} や$, 表面を構 成する原子とは異なる原子からなる探針で測定された LBH がバイアス極性依存性を示すこと ${ }^{20)}$ な゙，試料表 面と探針の仕事関数の違いからは説明できない結果があ る。さらに, 测定法による LBH の探針試料間距離依存 性やバイアス電圧依存性の振る舞いの違いも報告されて いる。例えば, Approach 法で測定された $\mathrm{Au}(111)$ 表面 上の LBH は探針試料間距離に依存せず，バイアス電圧 の増加とともに線形に減少する。一方, 同じ $\mathrm{Au}(100)$ 面 で Modulation 法の場合, 探針試料間距離の減少ととも に LBH も減少し，またバイアス電圧の増加とともに非 線形に減少する。このような測定方法による LBH の振 る舞いの違いの原因もよく理解されてはいない。

\section{3. 解析方法ならびに解析結果について}

\section{1 シミュレーション方法ならびにモデル}

前節の最後に述べたような課題を念頭に, 我々はシミ ユレーションによるLBH の解析に取り組んでいる。 LBH を測定に即した方法で評価するにはトンネル電流 を計算する必要があるが，既に述べたようにLBH はト ンネル電流の探針試料間距離依存性から評価するため, 通常の STM 像解析の場合より精度の高い計算が求めら れる。この目的にかなう, 電子の散乱状態を密度汎関数 法に基づき局所密度近似のもとで自己無撞着に計算する 手法が近年いくつか開発されている。ここでは我々のグ ループが開発した境界マッチング密度沉関数法 (Boundary-matching Scattering-state Density Functional Method = BSDF 法) ${ }^{20 \sim 23)}$ を用いてトンネル電流の計算を 行い, 得られたトンネル電流と（1）式を用いて LBH を評価した。

BSDF 法で得られた結果から, トンネル電子に対する 障壁高さを 2 つ方法で評価する。第一の方法は, （1） 式の微分を差分化した次式で障壁高さを評価することで ある。

$$
\phi_{\mathrm{LBH}}(d)=0.952\left(\frac{1}{\Delta d} \operatorname{In} \frac{I_{\mathrm{t}}(d+0.5 \Delta d)}{I_{\mathrm{t}}(d-0.5 \Delta d)}\right)
$$

ここで $d$ と $\Delta d$ は探針試料間距離と探針の変調振幅で あり, $\Delta d$ は測定で用いられる $0.21 \AA$ とした。また, ト ンネル電流 $I_{\mathrm{t}}$ は BSDF 法により得られたものを用いる。 この方法で得られた障壁高さは, 测定で得られる LBH 
に直接対応するものである。第二の方法は, BSDF 法計 算で決定される有効ポテンシャルを用い，探針原子を通 り表面に垂直な直線上の有効ポテンシャル分布の最大值 を最大障壁高さ (Maximum Barrier Height, 以下 MBH) と定義することである。その定義から，MBH はトンネ ル電子が感じる有効ポテンシャルの大きさを表す指標と して用いることができる。

Fig. 1 に解析に用いたモデルを示す。試料表面とし て, Fig. 1（a）と（b）に示す理想 $\mathrm{Al}(100)$ 表面と（c) に示す表面第 2 層に空孔欠陥がある $\mathrm{Al}(100)$ 表面を用い た。以下，これらのモデルを理想表面と欠陥表面と呼ぶ こととする。欠陥表面のモデルは構造最適化を考慮して いないので, 不安定で非現実的なモデルである。しか し, LBHへの試料表面の原子構造の影響を調べるため には有用であろう。なお，探針は $\mathrm{Al}$ 原子 1 個でモデル 化した。

\section{2 理論計算による LBH 像}

Fig. 2 に，探針試料間距離が $5.9 \AA$ の場合の $\mathrm{Al}(100)$ 理 想表面のトンネル電流像, LBH 像, MBH 像を示す。こ こで探針試料間距離は，探針原子の中心から表面原子の 中心までの距離である。Fig. 2 より, トンネル電流像と
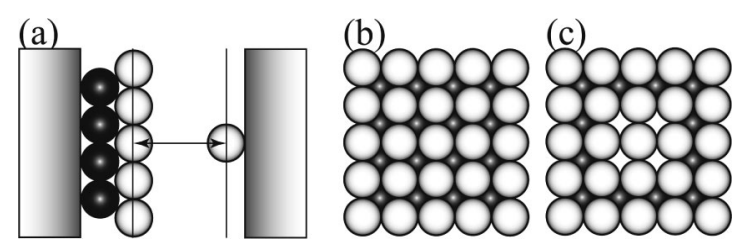

Fig. 1. Schematic representation of the present tip-surface system : (a) a side-view of the system, (b) the surface model of the defectless sample and (c) the surface model of the defective one. Bright circles are $\mathrm{Al}$ ionic cores in the outermost layer and dark circles are $\mathrm{Al}$ ionic cores in the second layer. In the surface model (c), four $\mathrm{Al}$ atoms are missing in the second layer. Arrow shows the tip-sample distance.
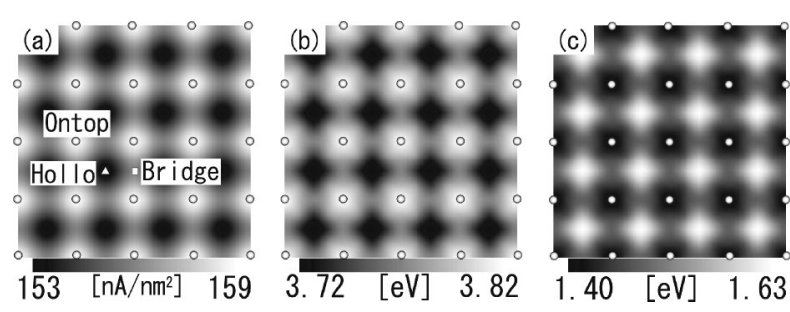

Fig. 2. Calculated images of (a) tunneling current, (b) local tunneling barrier height, and (c) maximum barrier height for tip-sample distance of 5.8 $\AA$. Bright circles indicate the center of $\mathrm{Al}$ ionic cores in the first layer and the ontop sites.
LBH 像が同じコントラストを示すことがわかる。多く の場合に測定で得られる STM 像と LBH 像が同じコン トラストを示すという点で, この結果は実験結果と一致 する ${ }^{3,4,24)}$ 。さらにトンネル電流像と $\mathrm{MBH}$ 像が逆のコン トラストを示すことは, MBH の物理的な意味から理解 できる。また LBH 像と MBH 像が互いに逆のコントラ ストを示すことから, LBH は「表面の原子レベルの仕 事関数」と直接には対応していないこともわかる。な お, 探針試料間距離を変化させても像のコントラストは 逆転しない。

\section{3 試料表面の原子構造の LBH への影響について}

Fig. 3 に $\mathrm{Al}$ (100) 理想表面と欠陥表面上の Ontop 位置 での $\mathrm{LBH}$ と $\mathrm{MBH}$ のバイアス電圧依存性を示す。バイ アス電圧は, 試料表面のフェルミレベルが探針のフェル ミレベルよりも高い場合を負バイアス電圧, 逆の場合を 正バイアス電圧と定義する。トンネル電子は, 負バイア ス電圧では試料表面側から探針側へ，また正バイアス電 圧では逆に移動する。この図から $\mathrm{LBH}$ と $\mathrm{MBH}$ のバイ アス依存性に関して3つの特徴を見ることができる。第 一の特徴は, 理想表面の LBH もバイアス極性依存性を 示すことである。つまり, 負バイアス電圧の LBH は常 に正バイアス電圧のそれよりも大きく, $\mathrm{MBH}$ も同様な バイアス極性依存性を示す。第二の特徴は, 久陷表面の LBH のバイアス極性依存性は, 理想表面のそれと逆の 依存性を示すことである。欠陷表面の場合, 正バイアス 電圧の LBH が負バイアス電圧のそれよりも大きい。し かし, 欠陥表面の $\mathrm{MBH}$ は, 理想表面の $\mathrm{MBH}$ と同様の バイアス極性依存性を示す。第三の特徵は, 久陷表面の 場合, 正バイアス電圧の変化に対して LBH は非線形な
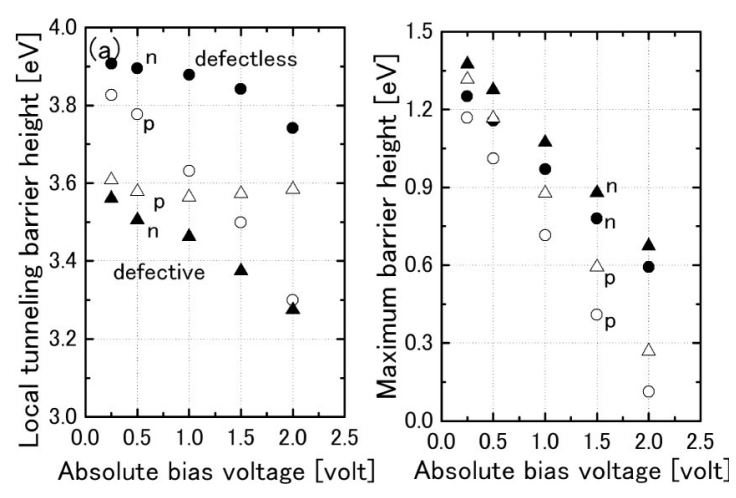

Fig. 3. Maximum barrier height $(\mathrm{MBH})$ and local tunneling barrier height $(\mathrm{LBH})$ of the (a) defectless and (b) defective samples. Open and solid circles denote the $\mathrm{MBH}$ for the positive and negative bias voltages, respectively. Open and solid triangles denote the LBH for the positive and negative bias voltages, respectively. 
振る舞いをするが，それ以外の場合の LBH はバイアス 電圧の増加とともに単調に減少することである。なお実 験では, $\mathrm{Au}(111)$ 表面上の LBH について, バイアス電 圧の増加とともに減少すること的扔よび正バイアス電圧 の LBH が負バイアス電圧のそれよりも大きいというこ と ${ }^{19)}$ が報告されている。

\section{4 探針原子種の LBH への影響について}

Fig. 4 に $\mathrm{Al}$ 探針と $\mathrm{Na}$ 探針の場合の $\mathrm{Al}$ (100) 表面の LBH と MBH の探針試料間距離依存性を示す。Fig. 4 に 見られる特徵は, $\mathrm{Al}$ 探針と $\mathrm{Na}$ 探針の $\mathrm{LBH}$ の差が, 全 ての探針試料間距離で MBH の差よりも大きいことであ る。探針原子の仕事関数の差よりも LBH の差の方が大 きいという点で，この結果は実駼結果と一致する ${ }^{20)}$ 。次

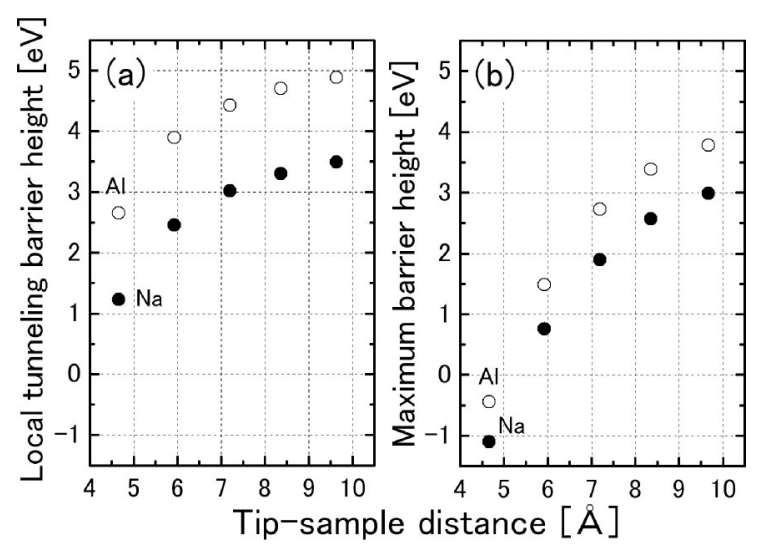

Fig. 4. (a) Local tunneling barrier height and (b) maximum barrier height calculated with $\mathrm{Al}$ and $\mathrm{Na}$ tips. Open and solid circles denote the $\mathrm{LBH}$ and $\mathrm{MBH}$ for the $\mathrm{Al}$ and $\mathrm{Na}$ tips, respectively.

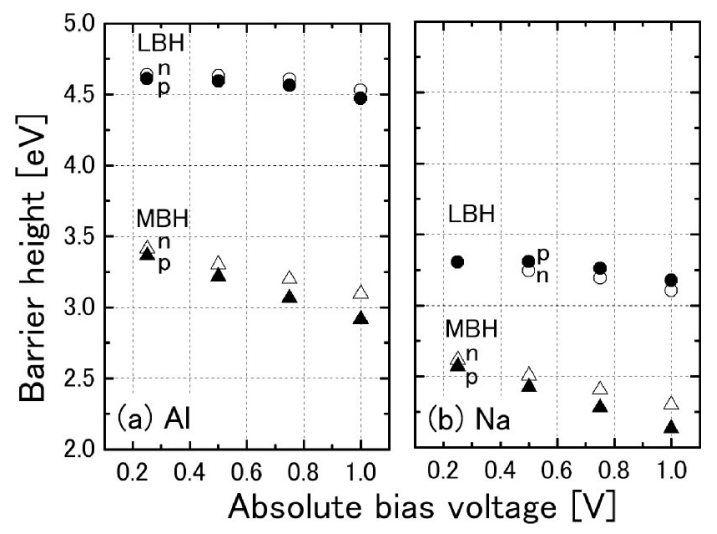

Fig. 5. Local tunneling barrier height and maximum barrier height of (a) $\mathrm{Al}$ and (b) Na tips. Open and solid circles denote the LBH for the negative and positive sample bias voltages, respectively. Open and solid triangles denote the $\mathrm{MBH}$ for the negative and positive sample bias voltages, respectively.
に Fig. 5 に $\mathrm{Al}$ 探針と $\mathrm{Na}$ 探針の場合の $\mathrm{Al}(100)$ 表面の LBH と MBH のバイアス電圧依存性を示す。Fig. 5 から 探針原子種によって LBH が逆のバイアス極性依存性を 示すことがわかる。つまり, Na 探針の場合, 負バイア ス電圧の LBH が正バイアス電圧のそれよりも常に大き いが, $\mathrm{Al}$ 探針の場合には正バイアス電圧の LBH の方が 負バイアス電圧のそれよりも常に大きい。一方 $\mathrm{MBH} の$ 方は，探針原子種に依らず，負バイアス電圧の $\mathrm{MBH}$ が 正バイアス電圧のそれよりも大きい。したがって, Al 探針の場合には LBH と MBH は同じバイアス極性依存 性を示すが, Na 探針の場合には LBH と MBH は逆のバ イアス極性依存性を示す。

\section{5 測定方法の違いについて}

Fig. 6 (a) に Modulation 法と Approach 法で得られた LBH のトンネルコンダクタンス依存性を示す。ここで
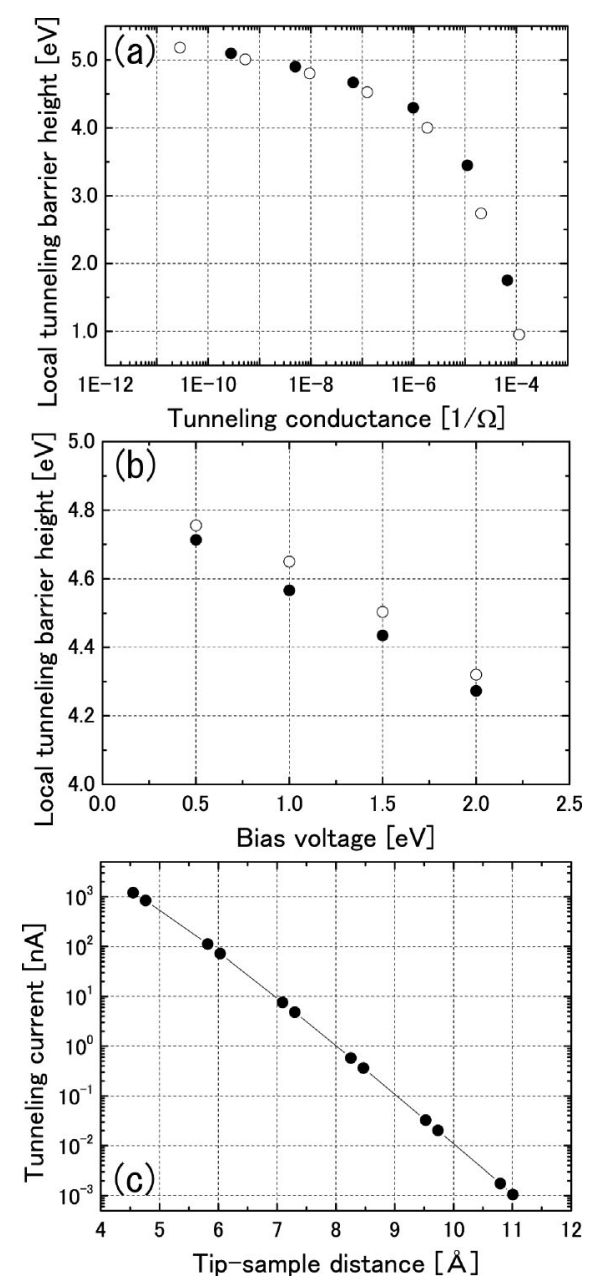

Fig. 6. (a) Tunneling conductance and (b) bias voltage dependences of the calculated LBH obtained by the modulation and approach methods. Open and solid circles denote the LBH values obtained by the modulation and approach methods, respectively. (c) Tip-sample distance dependence of tunneling current. 
はバイアス電圧を $50 \mathrm{mV}$ として計算を行った。また, Approach 法では，探針を試料表面から $1.5 \AA$ 動かしたと きの $\log I-\mathrm{z}$ 曲線を用いて LBH を評価した。Fig. 6 (a) から，トンネルコンダクタンスの広い領域 $\left(10^{-11} \sim\right.$ $\left.10^{-4} \mathrm{~S}\right)$ で二つの方法で得られた LBH にほとんど差が ないことがわかる。トンネルコンダクタンスが $10^{-11} \sim$ $10^{-8} \mathrm{~S}$ の領域での LBH の変化は, $10^{-6} \sim 10^{-3} \mathrm{~S}$ の領域 のそれよりも小さい。Approach 法による実験結果では, トンネルコンダクタンスが $10^{-9} \sim 10^{-7} \mathrm{~S}$ の領域で LBH の変化は小さい。一方 Modulation 法による実験結果で は, トンネルコンダクタンスが $10^{-8} \mathrm{~S}$ 以下の領域では LBH の変化は小さいが, トンネルコンダクタンスが $10^{-8} \mathrm{~S}$ 以上の領域ではトンネルコンダクタンスの増加に ともない LBH は減少する1)。したがって, 計算結果は 実験結果を完全には再現してはいないが，低コンダクタ ンス領域で変化が小さく, 高コンダクタンス領域で減少 する点に関しては穾験結果と一致するといえよう。

次に二つの測定法によるバイアス電圧依存性の違いを 見てみる。Fig. 6(b) に, 二つの方法で得られた LBH のバイアス電圧依存性を示す。この図から, 二つの方法 で得られた LBH がほぼ同じバイアス電圧依存性を示す ことがわかる。実験結果では二つの方法で異なるバイア 又電圧依存性が報告されているので，この結果は実験結 果を再現していない。

Fig. 6 （c）にトンネル電流の探針試料間距離依存性を 示す。この図より計算している探針試料間距離の範囲で は, トンネル電流は探針試料間距離の増加に伴い指数関 数的に減少することがわかる。

\section{4. 議}

論

前節で紹介した計算結果を踏まえて, 実験から評価さ れるLBH の物理的意味について考察してみたい。まず， （1）式で評価される量は, トンネル電流の表式から, 直接的には「局所的な仕事関数」より「真空中の波動関 数の減衰率」と結びついている点に留意したい。さら に，（1）式を導出する際には, 表面平行方向にはポテ ンシャルが完全に一様であるとして 1 次元の矩形ポテン シャルに帰着していたのに対して, 実際には表面平行方 向に原子スケールのポテンシャル変動が存在する。そこ で, LBHへの表面平行方向の運動の影響を陽に考えて みる。

Fig. 7 に 3 次元の真空ポテンシャル中の電子の運動エ ネルギーを表す概念図を示す。真空ポテンシャルをトン ネルする電子は, 表面垂直方向には $E_{z}$ の運動エネルギ 一を持つ。表面平行方向については, 波数の異なる成分 に分解して考えると, その運動エネルギーは $\left(\hbar \mathbf{k}_{\|}\right)^{2}$ /

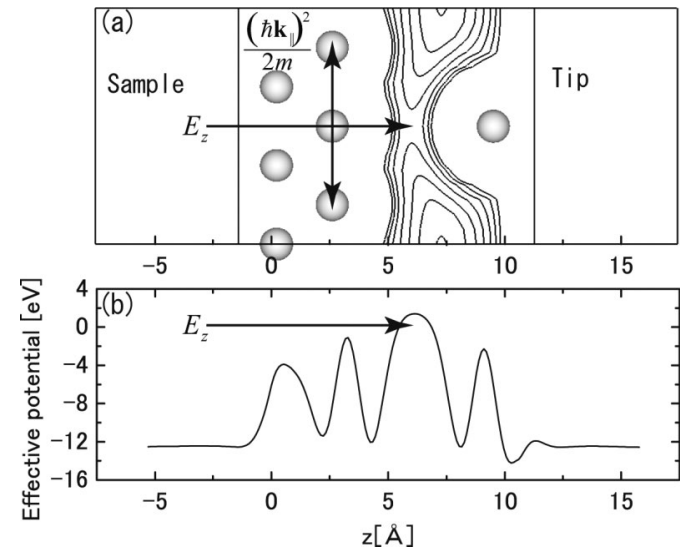

Fig. 7. Schematic representation of (a) the effective potential and (b) effective potential distribution on the line perpendicular to the surface. Allows show the motion of tunneling electrons in the directions normal to and parallel to the surface.

$2 m$ と表せる。ここで $\mathbf{k}_{\|}$は表面平行方向の波数ベクトル である。

真空中での波動関数の表面垂直方向の減衰率の 2 乗 $\kappa^{2}$ は, 簡単のために表面垂直方向の運動を分離した後 にWKB 法で評価すると, $\phi_{\mathrm{MBH}}-E+\left(\hbar \mathbf{k}_{\|}\right)^{2} / 2 m$ に比例 する。ここで $\phi_{\mathrm{MBH}}$ は $\mathrm{MBH}, E$ は電子の全エネルギーで ある。この減衰率の表式から，あるエネルギー $E$ を持 つ電子の場合, 表面平行方向の運動エネルギーの増加に より減衰率も大きくなることがわかる。害際には，表面 平行方向の波数が異なるトンネル電流が混在するので, LBH はこの減衰率の 2 乗のある重み付け平均であると 予想される。しかし, この重み付け平均の明確な表式を 求めることは難しい。そこで, LBHへの $\mathbf{k}_{\|}$の影響を評 価するために, 電子が表面垂直方向の運動に利用できる 運動エネルギー $E_{z}\left(E, \mathbf{k}_{\|}\right)=E-\hbar \mathbf{k}^{2} / 2 m$ に関する状態 密度を導入する。 $E_{1} \leq E \leq E_{2}$ のエネルギー領域での状態 密度 $D\left(E_{z}\right)$ を

$$
\begin{aligned}
D\left(E_{z}\right)= & \int_{\Omega} d \mathbf{r} \frac{2}{(2 \pi)^{3}} \sum_{\mathrm{i}=\mathrm{T}, \mathrm{s}} \int_{\sqrt{2 E_{1}}}^{\sqrt{2 E_{2}}} d k_{\mathrm{z}} \sum_{\mathrm{m}} \\
& \times \int d \mathbf{k}_{\|} \delta\left(E_{\mathrm{z}}-E_{z}^{\mathrm{m}}\right)\left|\Psi_{E, \mathbf{k} \|, k \mathrm{k}}^{\mathrm{i}}(\mathbf{r})\right|^{2}
\end{aligned}
$$

で定義する。ここで $\Psi_{E, \mathbf{k} \mid k, k}^{\mathrm{T}(\mathrm{S})}(\mathbf{r})$ は全エネルギー $E$ を持 ち探針（表面）から伝播する波動関数である。 $k_{\mathrm{z}}^{\mathrm{m}}$ は $E\left(\left(\mathbf{k}_{\|}+\mathbf{G}_{\|}^{\mathrm{m}}\right)^{2}+\left(k_{z}^{\mathrm{m}}\right)^{2}\right) / 2$ の関係から定義される。 $\mathbf{G} \|$ 緟さ 表面平行方向の逆格子ベクトルである。

次に，このように定義した $E_{z}$ に関する状態密度に基 づいて LBH の振る舞いを考察する。

まず， 3.3 で説明した試料表面の原子構造の LBHへの 影響の原因について検討する。Fig. 8 (a) と（b）にバ 


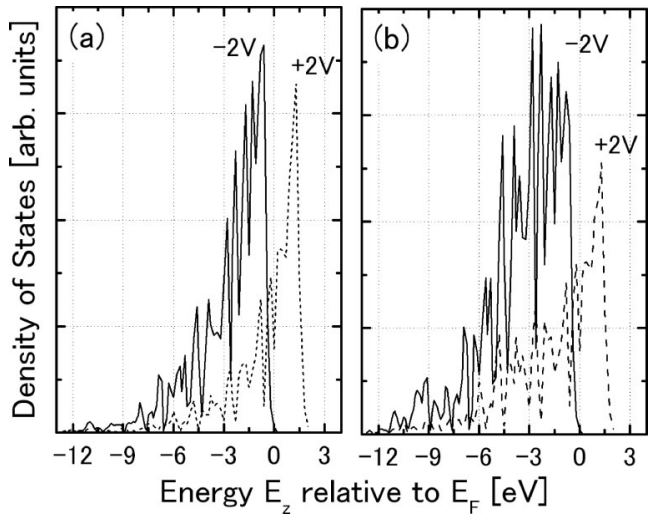

Fig. 8. Calculated electron density distribution of the (a) defectless and (b) defective samples as a function of the kinetic energy perpendicular to the surface $E_{z}$. Solid and dotted lines denote the electron density at the bias voltages of $-2 \mathrm{~V}$ and $+2 \mathrm{~V}$, respectively.

イアス電圧が $\pm 2 \mathrm{~V}$ の場合の $E_{z}$ に関する状態密度を示 す。本節の第 2 段落で説明したこととトンネル確率が $E_{z}$ の低下と共に急激に減少することとを考えると, 負 バイアス電圧の場合は試料側のフェルミレベル，正バイ アス電圧の場合は探針側のフェルミレベル（すなわち図 中の $+2 \mathrm{~V})$ 付近の $E_{z}$ に関する状態密度が減衰率扔よび LBH に大きく影響すると考えられる。この図から明ら かなように， $E_{z}$ に関する状態密度のフェルミレベル付 近の值のバイアス極性による差は, 理想表面の場合に比 べて欠陥表面の場合の方が大きい。 $E_{2}$ に関する状態密 度のバイアス極性による差が小さい場合, LBH のバイ アス極性依存性は MBH のバイアス極性依存性を直接反 映する。したがって，理想表面上の LBH のバイアス極 性依存性は MBH のそれに起因するといえる。一方， $E_{z}$ に関する状態密度のバイアス極性による差が大きい場合 には, LBH のバイアス極性依存性は MBH のバイアス 極性依存性と $E_{z}$ に関する状態密度のバイアス極性依存 性とを総合したものとなる。欠陥表面の場合，正バイア ス電圧の $\mathrm{MBH}$ はバイアス電圧の増加とともに減少する が, $\mathrm{LBH}$ は $+0.5 \mathrm{~V} \sim+2 \mathrm{~V}$ のバイアス電圧の範囲で増 加している。フェルミレベル付近の $E_{z}$ に関する状態密 度が小さいと減衰率拈よび LBH は大きくなること, ま た Fig. 8（b）から $E_{z}$ に関する状態密度はフェルミレベ ル近傍でバイアス電圧 $-2 \mathrm{~V}$ の状態密度の方が $+2 \mathrm{~V}$ の それよりも大きいことから，バイアス電圧 $+2 \mathrm{~V}$ での状 態密度の減少が LBH の増加を引き起こした原因といえ る。

この $E_{z}$ に関する状態密度の減少は, 空孔欠陥の上の 表面原子上に局在化した表面状態が原因である。表面平 行方向に局在した表面状態を経由してトンネルする電子

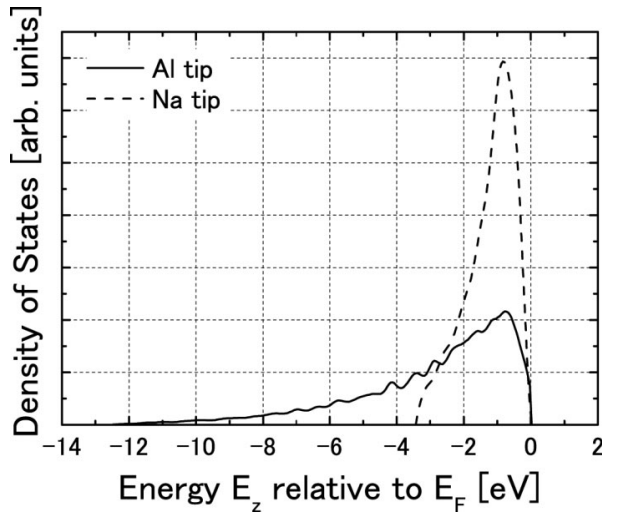

Fig. 9. Calculated density of states for $\mathrm{Al}$ and $\mathrm{Na}$ tips as functions of kinetic energy for motion in surface normal direction, $E_{\mathrm{z}}$. Solid and dotted lines denote the density of states for the $\mathrm{Al}$ and $\mathrm{Na}$ tip cases at the tip-sample distance of $8.4 \AA$, respectively.

は，この閉じ达め効果のために表面平行方向に高い運動 エネルギーが必要である。このため表面垂直方向の運動 に利用できるエネルギーが減少し，LBH は増加する。 正バイアス電圧における LBH の増加は, このように理 解することができる。

次に探針原子種の LBHへの影響の原因について検討 する。既に述べたように LBH は真空中の波動関数の減 衰率の 2 乗, つまり $\phi_{\mathrm{MBH}}-E_{\mathrm{z}}$ の重み付け平均であるの で, $\mathrm{Al}$ 探針と $\mathrm{Na}$ 探針の $\mathrm{LBH}$ の差 $\delta(L B H)=\phi_{\mathrm{LBH}}^{\mathrm{Al}}-\phi_{\mathrm{LBH}}^{\mathrm{Na}}$ は, $\delta(M B H)-\left(E_{z}^{\mathrm{Al}}-E_{z}^{\mathrm{Na}}\right)$ の重み付け平均といえよう。 ここで $\delta(M B H)=\phi_{\mathrm{MBH}}^{\mathrm{A}}-\phi_{\mathrm{MBH}}^{\mathrm{Na}}$ である。Fig.9に $E_{z}$ に関 する状態密度分布を示す。Fig. 9 より，Al 探針の場合に 比べ，Na 探針の場合の状態密度の方がフェルミレベル 付近に局在していることがわかる。この結果,

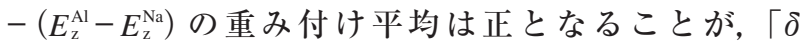
$(M B H)$ よりも $\delta(L B H)$ の方が大きい」という 3.5 に述 べた計算結果の原因である。さらに，この探針原子種に よる $E_{z}$ に関する状態密度分布の違いは，探針原子付近 の有効ポテンシャル分布の違いに起因することも計算結 果の解析から判明している。

また，探針原子種による LBH のバイアス電圧依存性 の違いも同様に $E_{2}$ に関する状態密度の違いから理解す ることができる。Fig. 10 に，試料表面と各探針の $E_{z}$ に 関する状態密度を示す。Fig. 10 から， Al 探針と Na 探針 の両方の場合で負バイアスの状態密度が正バイアスのそ れよりも大きいこと，そしてその差は $\mathrm{Na}$ 探針の場合の 方が $\mathrm{Al}$ 探針の場合に比べて大きいことがわかる。一方, 表面の $E_{\mathrm{z}}$ に関する状態密度は, $\mathrm{Al}$ 探針と $\mathrm{Na}$ 探針の場 合で大きな違いはない。これまでの考察と同様に，バイ アス電压が $\pm V_{0}$ の $\mathrm{LBH}$ の差 $\phi_{\mathrm{LBH}}^{V=+\mathrm{V}_{0}}-\phi_{\mathrm{LBH}}^{\mathrm{V}=-\mathrm{V}_{0}}$ は, 


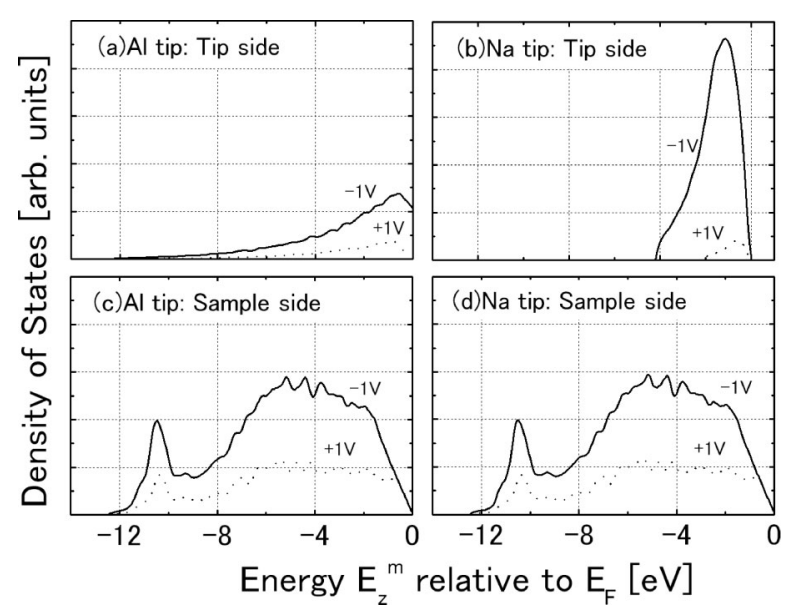

Fig. 10. Calculated density of states of samples and tips in $\mathrm{Al}$ and $\mathrm{Na}$ tip cases as functions of kinetic energy for motion in surface normal direction, $E_{z}$. Solid and dotted lines denote the density of states for the bias voltages of $-1 \mathrm{~V}$ and $+1 \mathrm{~V}$, respectively.

$\phi_{\mathrm{MBH}}^{\mathrm{V}=+\mathrm{V}_{0}}-\phi_{\mathrm{MBH}}^{\mathrm{V}=-\mathrm{V}_{0}}-\left(E_{\mathrm{z}}^{\mathrm{V}=+\mathrm{V}_{0}}\left(\mathbf{k}_{\|}\right)-E_{\mathrm{z}}^{\mathrm{V}=-\mathrm{V}_{0}}\left(\mathbf{k}_{\|}\right)\right)$の重み付け 平均であると考えることができるが，Fig. 10 に示した $E_{\mathrm{z}}$ に関する状態密度から， $-\left(E_{\mathrm{z}}^{\mathrm{V}=+\mathrm{v}_{0}}\left(\mathbf{k}_{\|}\right)-E_{\mathrm{z}}^{\mathrm{V}=-\mathrm{v}_{0}}\left(\mathbf{k}_{\|}\right)\right)$ の重み付け平均による $\mathrm{LBH} へ$ の補正は $\mathrm{Na}$ 探針の場合 の方が $\mathrm{Al}$ 探針の場合よりも大きいといえる。したがっ て, $\mathrm{Al}$ 探針と $\mathrm{Na}$ 探針でバイアス極性が異なる原因は, この $E_{z}$ に関する状態密度のバイアス極性による差であ るといえる。

最後にLBH の測定法について考える。この点につい ては, 我々の計算結果自体が実験で見られる測定法によ る LBH の違いを再現しておらず，測定法による LBH の バイアス電圧依存性の差は $E_{z}$ に関する状態密度からは 理解できない。そこで計算結果と測定結果の不一致の原 因として探針の弾性変形の効果に注目した。 $\mathrm{Au}$ 表面や $\mathrm{Si}$ 表面で探針試料間に働く力による弾性変形が LBH を 減少させるという報告がなされているからである ${ }^{25,26)}$ 。 この LBH の減少は, 力による変調振幅の変化が原因と されている。バイアス電圧の変化により探針先端の原子 に働く力が変化し, 変調振幅が変化する可能性がある。 この点を考察してみた。変調振幅の変化によって補正さ れる LBH は

$$
\phi_{\mathrm{LBH}}=0.952\left(\frac{\operatorname{In} I}{d s}\right)^{2}\left(1+\frac{1}{k} \frac{\Delta F}{\Delta z}\right)
$$

で表される。ここで $k$ は探針の弾性変形のばね定数, $\Delta F$ はトンネル方向の力の勾配, $d s$ と $\Delta z$ はそれぞれ探 針に働く力により補正された変調振幅と測定時に設定し た変調振幅である。 $d s$ は $d s=\Delta z+\Delta F / k$ と定義される。 Fig. 11 に探針原子に働く力の変化と $d s$ のバイアス依存

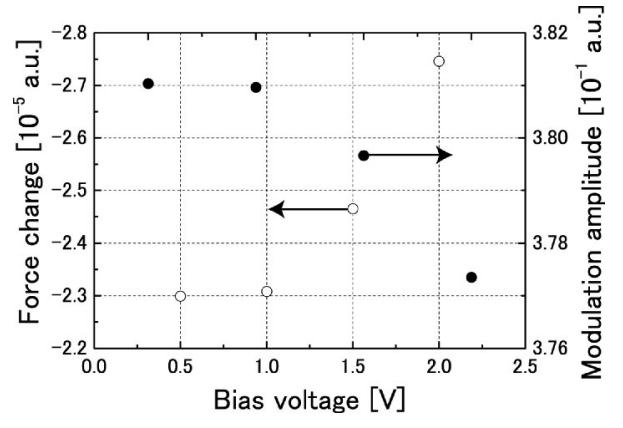

Fig. 11. Changes in calculated force and actual modulation amplitude. Open and solid circles respectively denote the changes in the calculated force by the ideal modulation amplitude and corrected modulation amplitude obtained using Eq. 3.

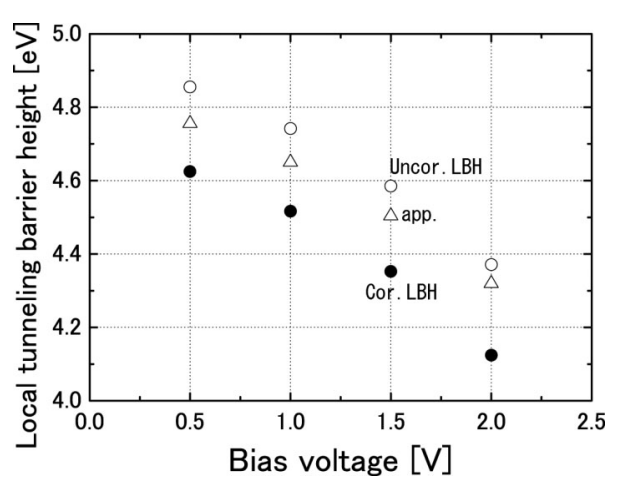

Fig. 12. Bias voltage dependence of $\mathrm{LBH}$ values obtained by the modulation and approach methods. Open and solid circles denote the uncorrected and corrected LBH values by the modulation method, respectively. Triangles denote the LBH obtained by the approach method.

性を示す。Fig. 11より探針に働く力により補正された 変調振幅 $d s$ は探針に働く力の勾配の影響でバイアス電 圧の増加とともに大きくなることがわかる。Fig. 12 に 探針に働く力によって補正された $\mathrm{LBH}$ と補正なしの LBH のバイアス電圧依存性を示す。Fig. 12 から補正さ れた LBH は, 補正なしの LBH と Approach 法による $\mathrm{LBH}$ よりも $5 \%$ 程度小さい。これは（3）式の $1+\Delta F /$ $(k \Delta z)$ に起因する。さらに, 補正された LBH のバイア ス電压依存性は, 低バイアス電圧では弱い非線形性を, 高バイアス電圧では強い非線形性を示す。これは印加さ れたバイアス電圧による電荷密度分布の変化が原因であ る。この結果は定性的には測定結果と一致するので, 測 定法による違いは探針の弾性変形の効果から理解できる 可能性があるといえる。 


\section{5.おわりに}

本稿では, STM によって測定される LBHへの表面原 子構造や探針原子種の影響, また, 二つの LBH 測定法 の違いの原因についての我々の理論解析の結果を紹介し た。LBH が局所的な仕事関数と直接的には対応しない ことも明確となったが，このような理論解析により測定 で得られる $\mathrm{LBH}$ の持つ物理的意味をよりはっきりさせ ることができたかと思う。

既に述べたように, LBH 測定はナノスケールの有機 分子膜のキャパシタンスの評価や半導体表面の欠陥種の 同定などで利用されている。これは仕事関数が試料表面 の電気二重層の変化に敏感だという特性を LBH が反映 しているということである。したがって, 表面の原子構 造や吸着分子の影響などにより表面の電荷密度分布が変 化したところでは, LBH 測定により新しい情報を得ら れる可能性があると期待できる。

現在, $\mathrm{Si}(100)$ 表面上の LBH の計算も行っている。金 属表面と異なり, 半導体表面上の場合, LBH は表面状 態や探針により誘起されるバンドベンディングなどの影 響も受ける可能性がある。予備的な計算によると, 金属 表面とは異なる探針試料間距離依存性やバイアス電圧依 存性を示すことがわかっている。これらの点を詳細に解 析すること, さらに半導体表面上の $\mathrm{LBH}$ へ不純物の 影響などを調べることは今後の課題である。

なお，局所的な仕事関数を測定する方法として，本稿 で取り上げた LBH 以外に接触電位差を利用したケルビ ン力顕微鏡 ${ }^{27)}$ による計測も有効な手段として用いられて いる。ケルビン力顕微鏡で得られる局所仕事関数と LBH とがどのように関連するかという点も, 興味深い 今後の課題と思われる。

\section{謝辞}

この研究の一部は科学技術振興機構戦略的創造研究推 進事業（CREST）の研究助成によって行われた。境界 マッチング密度汎関数プログラムの開発は合田義弘氏, 古家真之介氏, 胡春平氏によるものである。また, CREST メンバーの門平卓也氏および東京理科大学の渡 辺一之教授には理論家の立場から有益なアドバイスをい ただいた。さらに, 筑波大学の佐々木正洋助教授, 物 質・材料研究機構の吉武道子氏, 柳生進二郎氏, 京都大 学の黑川修氏には実験家の立場から有益なコメントをい ただいた。ここに感謝の意を表す。

\section{文献}

1) Y. Kuk and P.J. Silverman : J. Vac. Sci. Technol. A8, 289 (1990).

2) Y. Hasegawa, J.F. Jia, K. Inoue, A. Sakai and T. Sakurai : Surf. Sci. 386, 328 (1997).

3) J.F. Jia, K. Inoue, Y. Hasegawa, W.S. Yang and T. Sakurai : Phys. Rev. B 58, 1193 (1998).

4) H. Fukumizu, S. Kurokawa and A. Sakai : Surf. Sci. 441, 542 (1999).

5) R.J. Hamers and U.K. Kohler : J. Vac. Sci. Technol. A7, 2854 (1989).

6) R.W. Zehner, B.F. Parsons, R.P. Hsung and L.R. Sita : Langmuir 15, 1121 (1999).

7) M. Komai, M. Sasaki, R. Ozawa and S. Yamamoto: Appl. Surf. Sci. 146, 158 (1999).

8) H. Fukumizu, S. Kurokawa and A. Sakai : Surf. Sci. 441, 542 (1999).

9) R. Akiyama, T. Matsumoto and T. Kawai : Phys. Rev. B 62, 2034 (2000).

10) H. Totsuka, Y. Gohda, S. Furuya and S. Watanabe : Jpn. J. Appl. Phys. 41, 1172 (2002).

11) H. Totsuka, Y. Gohda, S. Furuya and S. Watanabe : Phys. Rev. B 70, 155405 (2004).

12) H. Totsuka, S. Furuya and S. Watanabe : Jpn. J. Appl. Phys. 44, 5459 (2005).

13) H. Totsuka, S. Furuya and S. Watanabe : Ultramicroscopy in press.

14) Y. Yamada, A. Sinsarp, M. Sasaki and S. Yamamot : Jpn. J. Appl. Phys. 41, 7501 (2002)

15) Y. Yamada, A. Sinsarp, M. Sasaki and S. Yamamoto : Jpn. J. Appl. Phys. 42, 4898 (2003).

16) S. Yagyu and M. Yoshitake: J. Vac. Sci. Technol. A21, 1294 (2004).

17) J.R. Hahn and H. Kang : Phys. Rev. B 60, 6007 (1999).

18) S. Yagyu and M. Yashitake : Surf. Sci. 532, 1136 (2003).

19) S. Kurokawa, Y. Yamashita, A. Sakai and Y. Hasegawa : Jpn. J. Appl. Phys. 40, 4277 (2001).

20) W. Mizutani, T. Ishida, N. Choi, T. Uchihashi and H. Tokumoto: Appl. Phys. A72, S181 (2001).

21) Y. Gohda, Y. Nakamura, K. Watanabe and S. Watanabe : Phys. Rev. Lett. 85, 1750 (2000).

22) S. Furuya, Y. Gohda, N. Sasaki and S. Watanabe : Jpn. J. Appl. Phys. 41, 989 (2002).

23) Y. Gohda and S. Watanabe : J. Phys. : Condens. Matter 16, 4685 (2004).

24) D. Ostermann, G. Walther and K.D. Schierbaum : Phys. Rev. B 71, 235416 (2005).

25) S.C. Meepagala and F. Real : Phys. Rev. B 49, 10761 (1994).

26) C.J. Chen and J. Hammers : J. Vac. Sci. Technol. B9, 503 (1991).

27) N. Nonnenmacher, M.P. O’Boyle and H.K. Wichramasinghe : Appl. Phys. Lett. 58, 2921 (1991). 